\title{
The immigrant other: Lived experiences in a transnational world
}

\author{
Rich Furman, Greg Lamphear, \& Douglas Epps (Eds.), 2016 \\ Columbia University Press, New York, NY \\ ISBN 978-0-23117-1816, pp. 292, paperback, NZ\$ 57
}

$T$ The Immigrant Other is a powerful and heart-rending presentation of the lived experiences of immigrants who struggle to survive in their transnational space, sometimes pejoratively termed and treated as aliens, and yet are criminalised, detained, incarcerated and deported, often resulting in agonising separation from those most dear to them including their spouse and children. The editors, Rich Furman, Professor of Social Work at the University of Washington, Douglas Epps, a former detention officer and current practising social worker in the USA, and Greg Lamphear have determinedly given a strong presence of authors who are social workers and community activists, and "chapters that reflect experiences that occur within community-based contexts," with the aim of focussing on "lived experiences of undocumented people in transnational spaces" (p. 2).

Migration and asylum-seeking occur perennially for various reasons including conflict and violence that leave no room for people's continued existence in their country and no choice except to escape to another as refugees. Hope of economic progress and providing financial assistance to dependent family members are also compelling reasons for daring ventures to more affluent countries. And yet, political rhetoric of leaders and rulers reverberate globally with disdainful portrayal of migrants as the Other and as enemies whose entry has to be thwarted in the first instance and deported if found living as "undocumented," "fugitive," "criminal" aliens within a country's geographic boundaries. It does not matter whether they lived there peacefully and within the law for more than a decade or two, their inability to provide documental evidence of lawful stay when they are caught is reason enough for detention and deportation-to the dismay of their children, spouse and dependants who often become mute spectators of the wanton drama unfolding before them that engenders separation, distress, helplessness, powerlessness, and loss of dignity. The authors have, in an uncompromising style, captured these sentiments and given voice to the people who live a life of invisibility in a hostile land. The narratives reveal individual struggle and collective resistance, which challenge the powers that criminalise them.

The book's introductory chapter outlines a justification for the title, intentions of the authors, summary of chapters and the history of how this book came aboutfrom a compelling realisation of a need to devote a book to capture the lived experiences of immigrants. The first editor, Professor Rich Furman, co-edited a book entitled The Criminalization of Immigration: Contexts and Consequences (Ackerman \& Furman, 2014) that examined legalistic and policy frameworks that criminalised immigration and highlighted the void that existed in relation to the "lived experience of the impact of these laws, systems, and structures" (p. 2). Douglas Epps, a former detention officer himself, wrote an autoethnography that described his experience in that job providing a powerful narrative of "structural violence." The experience of these two editors paved the way for the book. The publication was conceived with the aim of 
privileging the voices of immigrants, and the authors have, to their credit, done this job convincingly. The extremely memorable narratives in the book paint moving pictures of undocumented immigrants in the USA, Mexico, Spain, Australia, Canada, Greece, and Qatar and provide comparisons across the globe of the treatment meted out to immigrants by the guardians of national and state immigration laws and regulations.

A criticism of the book could be its overemphasis on narratives from America as nearly the entire first half of the book gives narratives of immigrants in America such as the Muslims facing discrimination, struggles of Latino day labourers, agonising stories of Brazilian parents horrified at facing separation from their children, and Filipino immigrants living in fear of deportation. However, the country being the "land of opportunity" attracts the highest number of immigrants even today and the editors' efforts, therefore, can be justified.

Although a happenstance, it seems apt that the publishing of the book coincides with the presidential election campaigns in the US where a calculated propaganda of a leading party is the war on terror that sentimentalises insecurities related to the presence of immigrants in the country. Constructing boundary walls to prevent immigration and immediate deportation of undocumented immigrants was repeated propaganda aimed at vote bank politics. Power elites have shrewdly supported the propaganda machinery. For instance, the work of Ken Rogoff, a Harvard economist, entitled The Curse of Cash proposes total elimination of paper currency to defeat social ravages such as illegal immigration problems in the US. His argument is that the flow of illegal immigration will shrink drastically because the absence of paper currency will abate the lure of jobs as American employers will not be able to pay illegal workers in cash. Rogoff's work is certainly an elitist manifesto designed to privilege them while dehumanising and disenfranchising "the Other".

As the editors aptly claim, this book will be of interest to students, practitioners and scholars from varied disciplines and, most significantly, to those "who provide services to undocumented people and also those who teach those who will engage in this work" (p. 3). Grassroots level activists and practitioners engaging in this work will find the book particularly useful because of its focus on community narratives, but the insights can equally be illuminating for policy makers and leaders.

The Immigrant Other is a "must read" for all those interested in making constructive changes to the lives of immigrants who live with constant fear of deportation in transnational spaces that have dehumanising systems to criminalise them and thwart their survival.

\section{References}

Ackerman, A., \& Furman, R. (2014). The criminalization of immigration: Contexts and consequences. Durham, NC: Carolina Academic.

Rogoff, K. S. (2016). The curse of cash. Princeton, NJ: Princeton University Press. 